\title{
Ecological Intelligence Level Of Hight School Students In Cimahi City
}

\author{
Revi Mainaki; Wanjat Kastolani ; Iwan Setiawan \\ Master Program of Geography Education, School of Post Graduate Indonesia University of \\ Education, Bandung
}

\begin{abstract}
Indonesia is experiencing serious environmental problems as a negative impact of development. One of the areas that shows the problem of the environment is Cimahi City located in West Java Province. Therefore, efforts are needed to prepare future generations in order to have high ecological intelligence. The intelligence can be prepared and established through the process of education in the School. The purpose of this study is to measure the level of ecological intelligence of high school students in Cimahi City. This research uses survey method based on quantitative approach. The technique of determining the number of samples using stratified ramdom sampling and obtained 35 schools as sample. Data collection techniques used observation, interviews, questionnaires, literature studies and documentation studies. Data then analyzed and presented with descriptive statistic technique. The results showed that the level of ecological intelligence of learners varied between schools, from moderate to high levels. Judging from the components of ecological intelligence, the attitude aspect has the highest score followed by aspects of knowledge, skills and participation. All parties need to encourage schools and learners to improve ecological intelligence through various programs at schools based on environmental conservation efforts.
\end{abstract}

Key word: Ecological intelligence, environmental degradation, knowledge, skills, participation

\section{Introduction}

\subsection{Backround}

When humans are in the century BC where life is highly dependent nature of humans are very appreciative of nature and indirectly become dependent as well. The fertile surface of the earth makes people more likely to think about other things, like science that gives rise to a more advanced civilization. This happened in the time of the Greeks and Romans when the needs of the population were fulfilled so much time to develop the science of the surrounding environment that led to the assumption that the environment as a human residence should be respected, preserved and preserved.

But this becomes a dilemma because it is in line with the progress of science and technology the higher the level of environmental damage, Data Potential kelurahan in Cimahi City (2009) and Puskesmas Cimahi Utara (2016) diseases caused by environmental degradation such as respiratory infections (ARI) About 5000 people, vomiting about 4400 people and dengue about 2,400 people showed the level of environmental degradation that can actually be prevented by growing the ecological intelligence of learners. The volume of 
vehicles passing through Cimahi City based on data from the Cimahi City Transportation Department (2016) reached 215,488 vehicles of various sizes, indicating high levels of air pollution caused by vehicles. A scientist in the field of psychology that is [2] Goleman (2010) in his book titled "Ecological Intelligence: The Hidden Impact of What We Buy" Considers that there is another growing intelligence, known as "Ecological Intelligence". Goleman described many of the human brain and mental maps as part of the intelligence, and how ecological intelligence began to form.

${ }^{[1]}$ Muhaimin (2015) and ${ }^{[2]}$ Goleman (2010) Explain the concept of human ecological intelligence can be measured through 1) knowledge of the impact of human activities, including know the impact we cause, how to impact a) Geosphere (spatial impact); b) Biosphere (impact on organisms); c) Socio-sphere (social impact); 2) attitude improvements favour ie care for the environment including transmitting his understanding to others (share the new knowledge with others); 3) skills in environmental conservation and 4) involvement in participatory, participatory environmental activities.

If people in this Cimahi City have ecological intelligence, the higher the awareness to use environmentally friendly vehicles or mass vehicles, in order to reduce air pollution in the city of Cimahi. Based on what has been described, showing that the growth of ecological intelligence in the City of Cimahi is very important, and interesting to study in a measurement and research with the title "Ecological Intelligence Level of Hight School Students In City Cimahi". With formulation of the problem in this research is "How is the level of ecological intelligence of high school students in Cimahi City? The puspose of resesrch is for identify and describe the level of ecological intelligence of high school students in Kota Cimahi. Theoretically, it is expected to enrich the study of theories of education and it is practically expected that this research can be input in determining the policy in the field of education and environment.

\section{Methodology}

The variables in this study are ecological intelligence with indicators that include (1) knowledge; (2) attitude; (3) skills and (4) participation in participating in preserving the environment of the learners themselves. The population in this study is all of the existing high schools in Cimahi City, consisting of 6 State Senior High School (SMAN), 10 Private High School (SMAS), 13 State Junior Secondary School (SMPN) and 24 Private Junior High School (SMPS) ) Spread throughout the existing outposts in Cimahi City. Through the Slovin equation described in ${ }^{[3]}$ Kusnendi (2008) using equation (1)..

$$
\mathrm{n}=\frac{N}{1+N \cdot \alpha^{2}}
$$

Description: $\mathrm{n}=$ Number of samples $\mathrm{N}=$ Population size

$\alpha=10 \%$ adjustment error rate adjusted by the researcher is the rest of the $90 \%$ confidence level

The sample of students of class XII IPS for senior high school and $9^{\text {th }}$ grade proportionally from 6065 was obtained 260 students with equation $2\left({ }^{[4]}\right.$ Sugiyono, 2010) ${ }^{\text {. }}$

$$
\mathrm{n}=\frac{\lambda^{2} \cdot N \cdot P \cdot Q}{d^{2}(N-1)+\lambda^{2} \cdot P \cdot Q}
$$

$\lambda=$ Chi Square $\mathrm{dk} 1$ and the level of error $10 \%=2.706$

$\mathrm{P} \quad=\mathrm{Q}=0.5 \quad \mathrm{~d}=0.05$ 
Data collection techniques used in this research are 1) observation; 2) questionnaire; 3) interview; 4) literature study; 5) documentation study. The data analysis technique used is by scoring the respondent's answer using measurement scale. Result measurement used Guttman scale ${ }^{[5]}$ for knowllege aspect (0-1 score), Linkert ${ }^{[6-7]}$ scale for attitude aspect (1-4 score) and Ratting scale ${ }^{[7-10]}$ for others aspect (1-5 score), then included in the following average equation (3).

Mean $=\frac{\sum X i}{N} \mathrm{Xi}=$ The value of $\mathrm{x}$ to $\mathrm{i}$ to $\mathrm{n} ; \sum=$ jumlah; $\mathrm{N}=$ amount of data

\section{Results}

The level of ecological intelligence of learners in high school country in Cimahi City can be seen as in Figure 1 where students in SMAN 3 are in the first sequence followed by SMAN 2 and beyond SMAN 6 and SMAN 5 Cimahi. Based on the calculation, the level of ecological intelligence of students in SMA Negeri in Kota Cimahi is in the classification of "high" score in order of SMAN 3 (2.74), SMAN 2 (2.71), SMAN 6 (2.69) and SMAN 5 (2.62) Differences in scores occur because there are also differences in scores on each aspect of the formation of the ecological intelligence of learners.
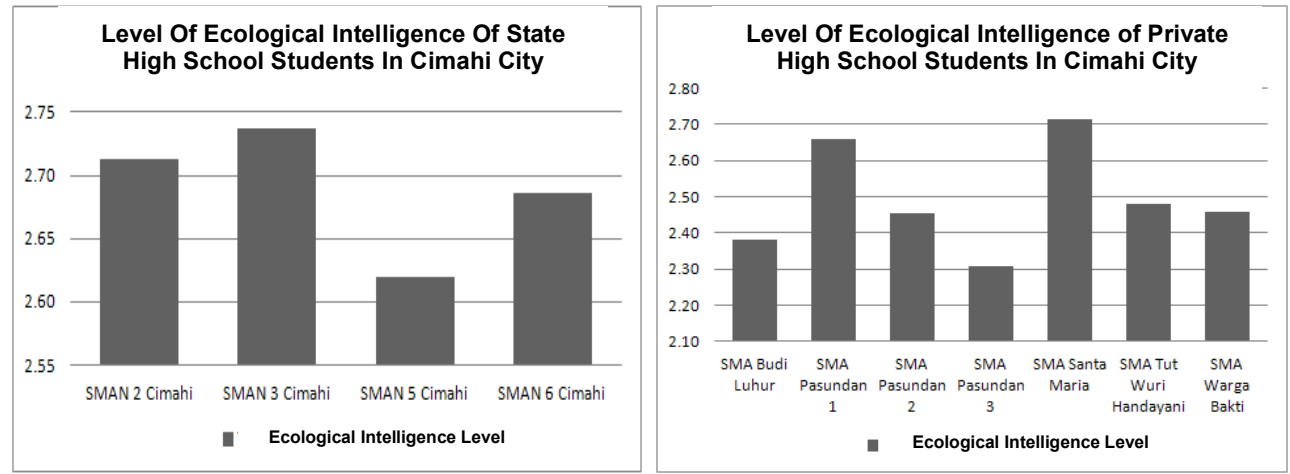

Figure 1 Level of ecological intelligence of state and private high school students in Cimahi City

The score of ecological intelligence level of private high school students in Kota Cimahi is in the "high" classification of SMA Santa Maria (2.71), Pasundan 1 (2.66), Pasundan 2 (2.46), Tut Wuri Handayani (2.48) and Residents Bakti (2.46) and school classification score "medium" SMA Budi Luhur (2.38) and Pasundan 3 (2.31). Overall, all SMP Negeri in Kota Cimahi have students with the classification of "high" score with the order SMPN Terbuka 2 Cimahi (2.72), SMPN 11 (2.66), SMPN 6 (2.62), SMPN 8 (2.55), SMPN 10 ( 2.55), SMPN 2 (2.55), SMPN 9 (2.52) and SMPN (2.40) score variations but still the "high" score range indicates differences in scores of each aspect.

It is seen that SMP Warga Bakti is first and SMP PGRI 3 Cimahi at the lowest level, the level of ecological intelligence of learners in private junior high school in Cimahi City is in the classification of "high" and "medium" score range. Out of 17 private high schools in the study sample, only 5 schools were classified as SMA Darma Kartini, Kartika Siliwangi, Muslimin Cibeureum, PGRI 3 and PGRI Leuwigajah and the rest were classified as "high" scores. 


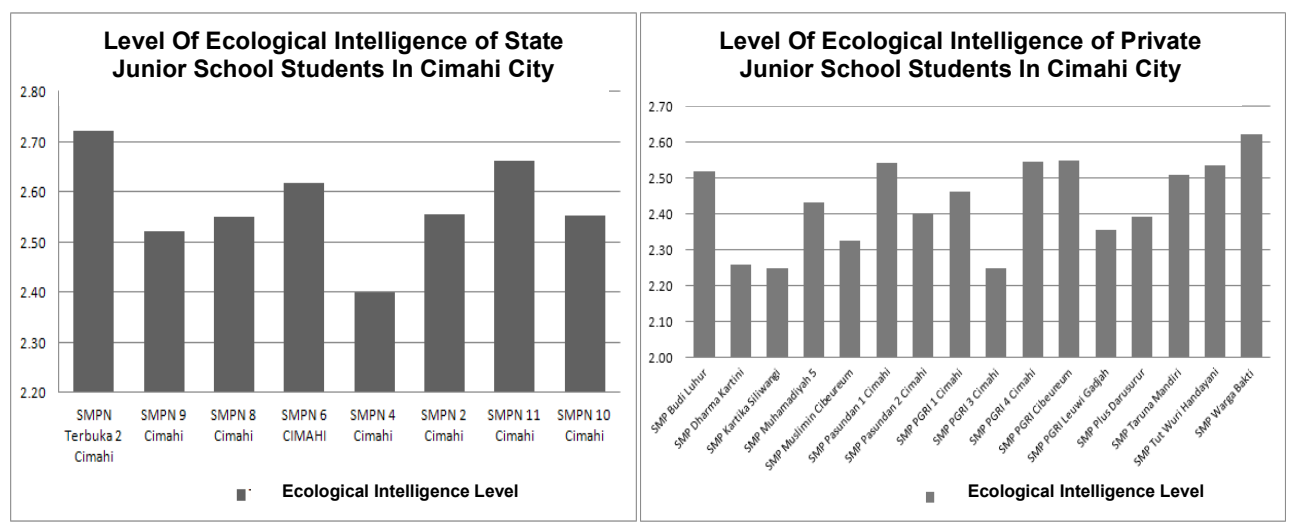

Figure 2 Level of ecological intelligence of students in state and privaet junior high school in cimahi city

\section{Discussion}

The cognitive social theory of Bandura and Mischel (in Pervin, 2010) ${ }^{[8]}$ of ecological intelligence is formed depending on the social interaction of learners, it also proves the exemplary aspect in the effort of environmental preservation to shape the ecological intelligence of learners, where exemplary in participating environment for the learners Principals, teachers and educators become the center of social models that shape the ecological intelligence of learners especially in the aspect of environmental preservation skills. According to ${ }^{[11]}$ Loughran (2002, pp. 35) experience alone does not lead to learning more than experience to create ecoloical intelligence. ${ }^{[12]}$ Tsiplakides \& Keramida (2010, pp. 22-26) find the correlation of teacher expectations as stated in the learning objectives, on the achievement and behavior of learners, the higher the teacher expectation, the higher the achievement of the learner and also ${ }^{[13]}$ Lynot and Woolfolk (1994, pp. 253-264) found a positive regression of learning towards the formation of learners' intelligence.

Many factors that affect the outcome of the learning process is the facilities or facilities and infrastructure, especially in the learning of geography because the infrastructure will help provide understanding to learners regarding the learning materials especially those related to environmental conservation efforts. ${ }^{[14]}$ Korir and Kikemboi (2014) research results show that intelligence, especially ecological intelligence can be influenced by the school environment in this case the school culture that has the content of the environment, especially aspects of supporting infrastructure. ${ }^{[15]}$ Odeh, et al (2015) also proved the influence of school culture in particular to shape aspects of attitude, skills and train the participation of learners.

School culture does not fully shape the ecological intelligence because the internal factors can also be one of the factors that influence the formation of ecological intelligence. Ecological intelligence is influenced by other factors one of which is an internal factor in accordance with Carl Rogers's phenomenological theory ${ }^{[16]}$ (Pervin, 2010) that intelligence is the perception of the individual and everyone has the ability to perceive the world, so that everyone's views are different as well as intelligence Ecologically everyone is different because of memory and processing factors in different human brains.

Proving Freud's psychoanalytical psychodynamic theory ${ }^{[16]}$ (Pervin, 2010) that everyone has a drive to do something, the drive is energy that is the response of environmental conditions, behavior that is influenced by environmental conditions. When receiving a response from the environment everyone will have the expression or discharge of different energy depending on the energy capacity it has, when looking at environmental conditions 
that are not appropriate environmental conditions then the response of each person will vary whether to leave it alone, whether to participate And damage it or vice versa. Makes the ecological intelligence of each person different depending on the energy in responding to environmental conditions.

According to the cognitive theory of Bandura and Mischel ${ }^{[16]}$ (Pervin, 2010) that everyone has different emotional impulses, it is related to the attitude aspect, the pro attitudes towards the environmental sustainability of each person is different depending on his drive to invite others In participating in preserving the environment and to what extent, and directly proportional to the biological theory that intelligence is highly dependent and is also determined by the capacity of the human brain itself.

When viewed carefully the various components of learning include goals, media, strategies and learning resources are all mengaju on making learners to understand the material of learning geography itself so that its contribution is smaller when compared with the school culture on the formation of the ecological intelligence of learners. Although the contribution is small, but geography learning continues to contribute to the formation of ecological intelligence because of the cognitive correlation formed with geographic learning materials that provide spatial understanding and knowledge, but ${ }^{[17]}$ Sylva (1994, pp. 136-171) statement was good output is good input, to create or build ecological intelligence need good input.

Habituation in school culture will shape attitude and skill aspects in environmental conservation efforts, attitudes and skill set will be rationalized by geography learning related to where learners are given understanding about spatial impact of human activities. The success of making students understand is very dependent of the condition of the learners themselves and depends on the content of the environment in various components of the learning of media geography whether it has been able to display the maximum issue, impact, solution and prediction of environmental problems that occur.

Exemplary will indirectly shape the skills aspect and also the learner's knowledge concerning the effort of environmental conservation, participatory become the event in expressing and applying various internal aspect of the learner related to ecological intelligence, participative aspect must be supported with school physical environment so that the participative activity implemented Can be realized properly, re-in this aspect of geography learning to be reinsforment in rationalizing must imitate exemplary principals, teachers and educators in environmental conservation.

\section{Conclusions}

Based on what is presented, it can be concluded that the level of ecological intelligence of high school students in Kota Cimahi varies from medium to high. Almost all aspects of knowledge, attitudes and skills have high scores in both public and private schools as well as in public and private secondary schools, while participatory aspects are in the classification of medium and low scores.

The level of ecological intelligence of learners in secondary schools in Cimahi City should be a description of the initial capital in the effort of environmental conservation in Cimahi City the participatory aspect is at the lowest score should be improved through the procurement of various programs regarding environmental conservation efforts. Aspects of knowledge, attitudes and skills with moderate to high scores should be maintained with the support of the school to make rules related to these three aspects.

Acknowledgments are especially for Allah SWT because thanks to his grace this paper can be solved as it should be, also to Rasulullah SAW who has brought us into a period of civilization. This paper is a form of publication of the final assignment in the Master Program of Geography Education, Graduate School, University of Education Indonesia. 
Acknowledgments to all parties who assisted the research include lecturers and staff in the Study Program, Cimahi City Education Department, all students, educators and senior high school education personnel in Cimahi City involved in this research and all parties who can not Mentioned one by one.

\section{Reference}

1. Muhaimin, Implementasi Model Pembelajaran Berbasis Masalah Lokal dalam Mengembangkan Kompetensi Ekologis Pada Pembelajaran IPS, Sosio Didaktika: Social Science Education Journal. 2, 1, 12-21 (2015).

2. D. Goleman. Ecological Intelligence The Hidden Impacts of What We Buy. (New York: Random House, 2010).

3. Kusnendi, Model-Model Persamaan Struktural Satu dan Multigroup Sampel dengan LISRE, (Bandung: Alfabeta 2008).

4. Sugiyono, Statistik Untuk Penelitian (Bandung: Alfabeta, 2011)

5. G. Guest. Using Guttman Scaling to Rank Wealth: Integrating Quantitative and Qualitative Data. Field Methods Journal, SAGE Publishing, 12, 4, 346-357, (2000).

6. H. Boone, D. Boone, D. Analyzing Likert Data. Journal of Extension. 50, 2, 1-15, (2012).

7. J.D. Brown. Likert items and scales of measurement?. Journal ALT Testing \& Evaluation SIG Newsletter. 15, 1, 10-15, (2011).

8. C.C. Preston, A.M Colman. Optimal Number Of Response Categories In Rating Scales: Reliability, Validity, Discriminating Power, And Respondent Preferences. Acta Psycoloica Journal Elsevier. 104, 1-15. (2000).

9. R.A. Westbrook. A Rating Scale For Measuring Product/Service Sactifation. Journal of Marketing. 44, 4, 68-72. (1986).

10. J. Loughran. Effective Reflective Practice In Search Of Meaning In Learning About Teaching. Monash University. Journal Of Teacher Education. 53, 1, 33-43. (2002).

11. I. Tsiplakides, A. Keramida. The Relationship between Teacher Expectations and Student: Achievement in the Teaching of English as A Foreign Language. ETL Journal. 3, 2, 22-26, (2010)

12. J. Lynot, Woolfolk. Teachers Implicit Theories of Intelligence and Their Educational Goals. The Journal Research dan Development Education. 27, 4, 253-264. (1994).

13. D.K. Korir, F. Kipkemboi. The Impact of School Environment and Peer Influences on Students' Academic Performance in Vihiga County, Kenya. International Journal Human and Social Science. 4, 5, 240, 251. (2014).

14. R. Odeh, O. Oguche, Angelina, E. Ivagher, Influence Of School Environment On Academic Achievement Of Students In Secondary Schools In Zone "A" Senatorial District Of Benue State, Nigeria, International Journal of Recent Scientific Research Research, 6, 7, 4914-4922, (2015).

15. L.A. Pervin, D. Cervon, P.O. John. Psikologi Kepribadian: Teori dan Penelitian Edisi Kesembilan. (Jakarta: Kencana Prenada Media Group, 2010).

16. Sylva, K. School Influences on Children's Development. J- Child Psychol Journal, 35, 1, 136-171. (1994). 